\title{
MANAGEMENT OF GREEN BUILDING DESIGN
}

\author{
${ }^{1}$ Mohamed Abdelaal Ibrahim and samara wad abd elhamed ${ }^{2}$ \\ ${ }^{1}$ Department Of Architecture, Faculty Of Eng., University Of Alexandria, Egypt \\ ${ }^{2}$ B.Sc. of Architecture University Of Alexandria
}

\begin{abstract}
The Green Building Revolution Is Sweeping across The World. It's A Revolution Inspired by an Awakened Under- Standing of how buildings use resources, affect people, and harm the environment. this revolution is further fueled by the knowledge that the world has little time to respond to the growing dangers of climate change, especially global warming, and that buildings play a huge role in causing carbon .

one of the first steps in the green Design process is to establish firm Environmental Goals For The Project. It Is Important To Set Specific Measurable Goals for Things Like Energy Efficiency, Water Conservation, On-Site Treatment of Rain Water And Storm Water, Material And Resource Management, Construction Waste Management. And we can discover the Benefits of Green Building In Light Of Climate Change throw Mitigation and Adaptation

Study The Green Building Design Process And Principles, The Research Discuss Integrated Design Process In General, Green Building Design Principles Are Building Shape And Orientation, Building Envelope (Heat Insulation And Building Density) And Solar Protection. ,Rating systems for green building and BIM technology to study building performance and its indictors are applied in a 3 case studies
\end{abstract}

\section{INTRODUCTION}

Green Buildings Are Part Of A Global Response To Increasing Awareness Of The Role Of Human Activity In Causing Global Climate Change. Buildings Account For More Than $40 \%$ Of All Global Carbon Dioxide Emissions, One Of The Main Culprits Implicated In The Phenomenon Of Global Warming. While The US And Western Europe, Canada And Japan Contribute The Majority Of Greenhouse Gas Emissions At The Present Time, This Situation Is Going To Change Dramatically In The Near Future. The Projected Rapid Growth Of Carbon Dioxide Emissions From China, India, and The Rest Of Asia, Brazil And Russia Make It Imperative That The Entire World Participate In Reducing The "Carbon Footprint" Of Urban Civilization Over The Next 30 Years. Global Temperature Increases Are Inevitable, With Significant Consequences for All Of the world. Many Observers Predict That Half The New Building Over The Next Three Decades Will Occur In China Alone, Some 220 Billion Square Feet Of New Space For Residential, Commercial And Industrial Uses. Without A Focus On Energy-Ancient And Green Buildings, We Have No Chance For Tackling Global Climate Change. The US And Other Developed Countries Need To Set A Leadership Example In Tackling Their Own Contributions To Carbon Dioxide Emissions. There Is Every Reason To Believe That This Is Not Only The Socially Responsible Thing To Do, But That It Will Be Good Business As Well, For The Entire World Soon Will Be Buying All Manner Of "Carbon Reduction" Technologies. As The Most Inventive Nation In The World, The US Is Poised To Reap Enormous Economic Advantage From Addressing Climate Change Issues In Buildings With New Technologies, Processes And Systems. By Doing So, We Will Not Only Grow Our Own Economy But Will Also Make A Major Contribution To The Global Problem 


\section{Paper problem}

Buildings Account For More Than 40\% Of All Global Carbon Dioxide Emissions, One Of The Main Culprits Implicated In The Phenomenon Of Global Warming.

Developing countries face a big problem in Energy consumption and the research discuss the process of design and construction a green building as a solution for Energy consumption and economic problems

\section{paper Aims and Objectives}

This paper aim to produce a frame work to be applied in green building construction process including design process, building performance measuring and construction steps and documentation. To tackle the previously mentioned aims the following objectives are to be achieved:

- The Effect of Architecture in the Environment at the End of the 20 Century Causing Climate Change, Global worming.... Etc.

- The Sustainable Development As A Result Of Climate Change And The Green Architecture Term Start To Be Used Sustainable Architecture And It's Result On The Architecture And The Environment.

- The Relation between Green Thinking, Green Community, Green Economic, Green Architecture Roles of Green Architecture.

- Green building design process and principals

- Green building performance study using BIM software

- The Rating Systems in Design, Performance and Construction.

- The construction of green building projects cost, obstacles and a comparison of traditional and green projects construction process

\section{The Global Warming, Reasons And Results}

\subsection{The Global Warming:}

The Greenhouse Effect Is a Natural Phenomenon That Is Essential to Keeping the Earth's Surface Warm. Like A Greenhouse Window, Greenhouse Gases Allow Sunlight To Enter And Then Prevent Heat From Leaving The Atmosphere. Water Vapor (H2O) Is The Most Important Greenhouse Gas, Followed By Carbon Dioxide (CO2), Methane (CH4), Nitrous Oxide (N2O), Halocarbons, And Ozone (O3). Human Activities Primarily Burning Fossil Fuels Are Increasing The Concentrations Of These Gases, Amplifying The Natural Greenhouse Effect. Image Courtesy Of the Marion Kosh land Science Museum of The National Academy Of Sciences. (Mazria, 2008)

\subsection{REASONS OF WARMING}

\subsubsection{Cultural \& Technical Transformation:}

Under Liberal Impetus, We Removed Social Roles and Allowed People To, Just By Having A line Of Personal Credit, Take On Responsibility For More Things Than They Can Biologically Understand (Mills, 2006.)

Approximately $90 \%$ Of Humanity Do Nothing But Consume Beyond Reason, Leave Behind A Huge Mess, And Then Blame Those In Authority For The Disaster The 90\% Have Created. Every "Revolution" Fits This Pattern, Although They Have A Narrative That Says Otherwise (Mills, 2006.)

There Was a Sudden Change and Increase in Man's Capacity to Have Control over Nature, Which By 17th Century Had Begun To Advance beyond The Technical Frontiers of Renaissance.

There Was Change In The Nature Of Human Consciousness, In Response To Major Changes Taking Place In The Society.

\subsubsection{The Human Sources}

The Main Sources Of Greenhouse Gases Due To Human Activity Are:

-Burning Of Fossil Fuels And Deforestation Leading To Higher Carbon Dioxide Concentrations.

-Land Use Change (Mainly Deforestation In The Tropics) Account For Up To One Third Of Total Anthropogenic $\mathrm{CO}_{2}$ Emissions. 
-Livestock Enteric Fermentation And Manure Management, Paddy Rice Farming, Land Use And Wetland Changes, Pipeline Losses, And Covered Vented Landfill Emissions Leading To Higher Methane Atmospheric Concentrations.

-Many Of The Newer Style Fully Vented Septic Systems That Enhance And Target The Fermentation Process Also Are Sources Of Atmospheric Methane.

-Use Of Chlorofluorocarbons (Cfcs) In Refrigeration Systems, And Use Of Cfcs Fire Suppression Systems And Manufacturing Processes.

\subsection{Results And Effects Of Global Warming \\ - The Urban Heat Island \\ - The Green Land Melting \\ - Current Sea Level Rise}

\section{Green Building and Sustainability:}

\subsection{Understanding Green Building and Sustainability}

The Terms 'Green' And 'Sustainable' Are Often Used Interchangeably But There Are Fundamental Differences Between Them. In A Clear Understanding Of These Differences Lies The Key To Understanding The Broad Range Of Theories, Agendas, Programs, Regulations, Technologies, And Techniques That Are Confusingly Put Together Under The Mantle Of 'Sustainable Building.

'Sustainable Building,' However, Refers More Precisely To The Goal Of Designing And Constructing Buildings That Have No Net Impact On The Environment, Such That A Total Built Environment Composed Of Similar Buildings Could Co-Exist With The World's Ecological Balance Indefinitely. Figure(1)

Green Building, Then, Focuses On Incremental Steps To Solve Known And Measurable Problems With Our Current Practice, Whereas Sustainable Building Seeks Models For An Unidentified Future State Of Society. Each Term Describes A Distinct Approach.

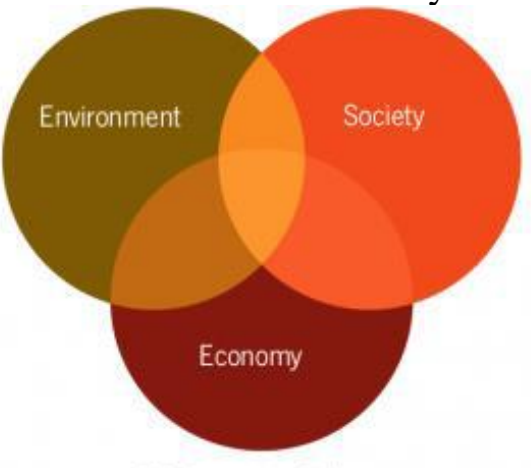

Weak sustainability

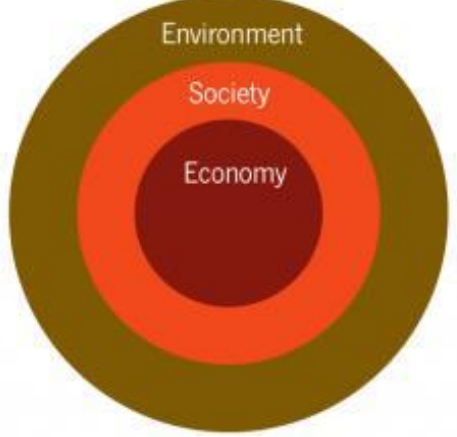

Strong sustainability

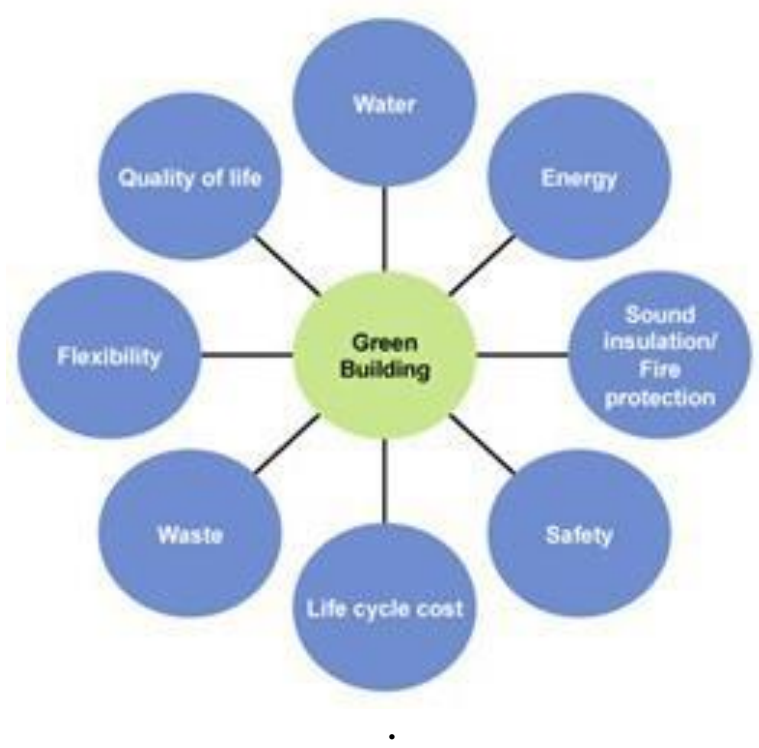




\subsection{Green Building Beginning, Goals and Objectives}

Once The Decision To Build Green Has Been Made, One Of The First Steps In The Green Design Process Is To Establish Firm Environmental Goals For The Project. This Is Often Done During What Is Called A Goal Setting Or Targeting Session. During This Session, It Is Important To Set Specific Measurable Goals For Things Like Energy Efficiency, Water Conservation, On-Site Treatment Of Rain Water And Storm Water, Material And Resource Management, Construction Waste Management, And To Assign Responsibility For Meeting These Goals To Specific Members Of The Design Team. Each Goal Needs A Champion Who Will See That Objective Through To The End. If The Building Is To Be Built In Accordance With The United States Green Building Council (USGBC) Leadership In Energy And Environmental Design (LEED) Green Building Rating System, It Will Be Helpful To Review The Requirements Of LEED As Part Of The Green Project Goal Setting Session, Begin Targeting Which Elements Of LEED Are Going To Be Pursued, And Establish Firm Criteria For Meeting Those Goals.

\subsection{Benefits of Green Building In Light Of Climate Change}

Significant Gains Can Be Made In Efforts To Combat Climate Change By Adopting Green Building Techniques. Highlighted Below Are Some Of The Opportunities That Green Building Presents.

\section{Mitigation}

- Reducing Energy

- Reduce Emissions and Pollution from Transportation of Materials

- Use Of Recycled Materials

- Accessible Public Transportation

- Compact Communities

Adaptation

Adaptation Refers To Actions That Can Be Taken To Adjust To The Impacts Of Climate Change. Planning For Adaptation Will Make Us Less Vulnerable To The Negative Impacts Of Climate Change. Green Building Will Makes Us More Adaptable To Climate Change In The Following Ways:

- Energy Sources

- Health And Comfort

- Reducing Water Supply Demand

- Water Efficiency

\subsection{The Economics Of Green Building}

The Economic Opportunity and Reduced Liability For Building Projects That Incorporate Green Building Measures. The Areas Covered Include Energy Efficiency, Water Efficiency, Waste Reduction, Construction, Building Operations And Maintenance, Insurance And Liability, Occupant Health And Productivity, Building Value, And Local Economic Development Opportunities.

- Energy Efficiency

- Water Efficiency

- Waste Reduction

- Construction

- building operations and Maintenance

- building Value

- Local Economic

3 GREEN BUILDING DESIGN AND PERFORMANCE MANAGEMENT

3.1 Green Building Design process and principles 
A Design Process That Integrates A Project Team Of Dedicated Professionals And Accounts For Project Location And Climate Is Essential For Successful Green Building . Design Success Is Achieved By Developing A Strong Green Building Project Team That Includes Design Professionals . Design Professionals Are Experienced Home Designers, Architects, Landscape Architects And Interior Designers Who Are Trained And Experienced In Green Building Techniques, Including Solar Design And Sustainable Site Planning. They Can Create A Vision That Reflects The Project's Goals And Budget. Project Teams Cannot Afford To Exclude Design Professionals; Doing So Will Likely Result In Higher Overall Project Costs, Poorer Green Performance And Missed Funding Opportunities . (Craig Nielson, LEED AP;Connie Baker Wolfe, 2009 )

\subsection{Integrated Design Process}

In General, The Integrated Design Process Is An Approach To Building Design That Seeks To Achieve High Performance On A Wide Variety Of Well-Defined Environmental And Social Goals While Staying Within Budgetary And Scheduling Constraints. It Relies Upon A Multidisciplinary And Collaborative Team Whose Members Make Decisions Together Based On Ashared Vision And A Holistic Understanding Of The Project. It Follows The Design Through The Entire Project Life, From Pre-Design Through Occupancy And Into Operation.

\subsection{Benefits Of Integrated Design}

IDP Provides The Biggest Payoff At The Beginning Of The Development Curve. The IDP Kickoff Session Should Bring Together Everyone Who Can Make A Difference, Contributing In A Structured Way, In Response To The Program And In Support Of The Sustainability Goals. Although This Might Seem Like A Blinding Flash Of The Obvious, Most Projects Don't Structure Their Development And Design Processes To Actually Take Advantage Of The Integrated Design Process. (Alex Zimmerman, 2009) (fig 2) ( fig 3)

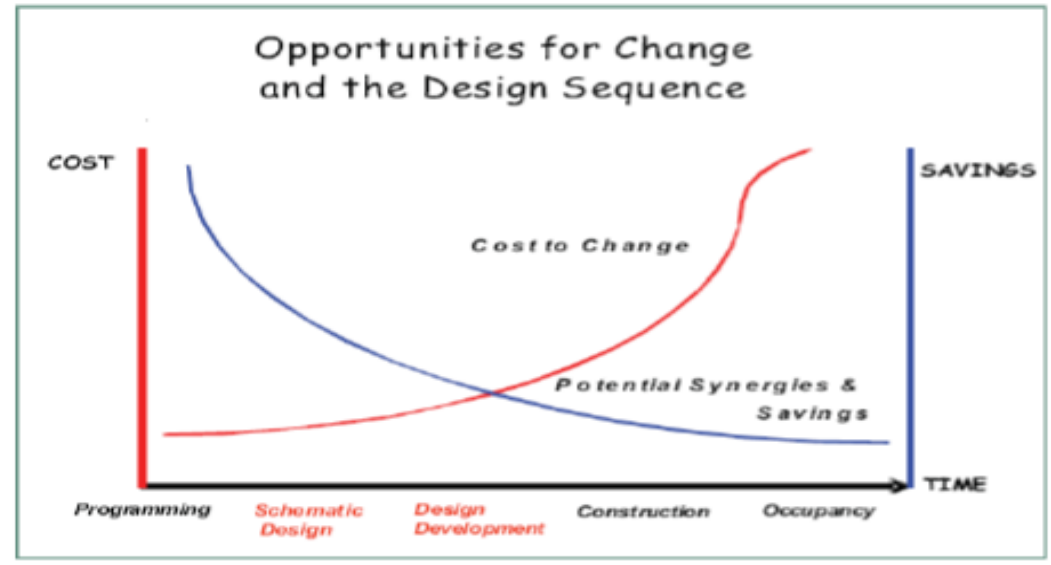

. Figure (2) (Alex Zimmerman, 2009) 


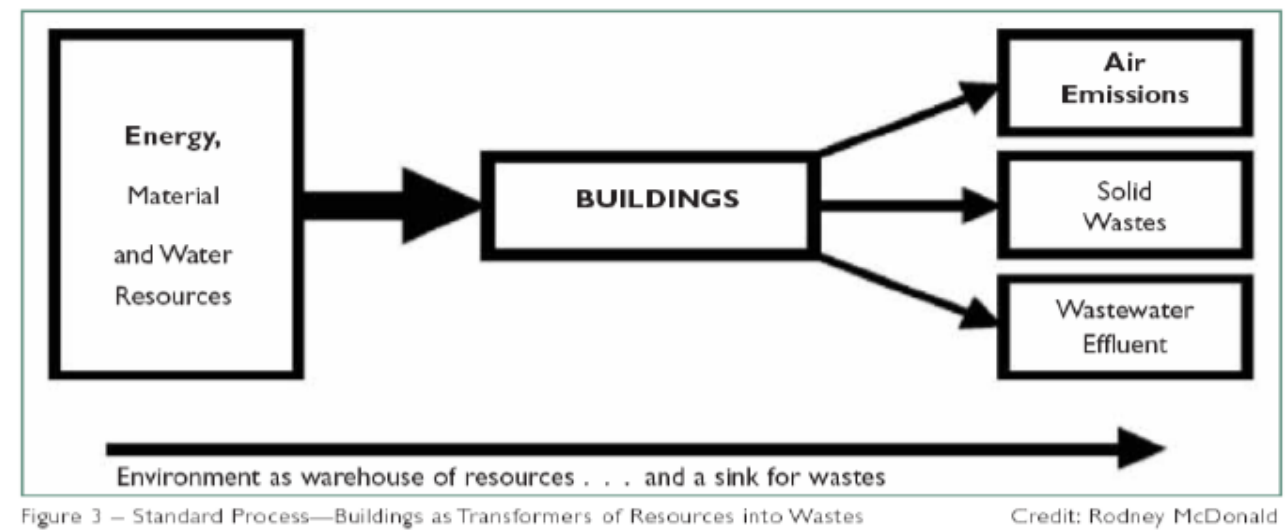

\subsection{Green Building Design principles}

. Figure (3) (Alex Zimmerman, 2009)

\subsubsection{Building Shape and Orientation}

The orientation of a given building especially of its transparent surfaces influences its energy budget due to the different heights from which solar radiation hits. Windows are elements of the envelope area of a building, which offer both heat insulation and passive heat gain. Correct orientation and dimensioning of windows is dependent on outdoor climate and utilization. For office rooms, solar gains can be exploited less than in residential settings.

An energetically correct positioning of utilization applications within an urban planning concept can be seen in figure (5) Shopping malls and recreational buildings, which require more sophisticated ventilation on account of dense occupancy, are usually placed close to heavily frequented roads. Residential and office buildings, in contrast, are generally placed in a more quiet area, in order to fully exploit natural ventilation potential. (Figure 6) shows what block shapes are the most favorable ones with equal use area.

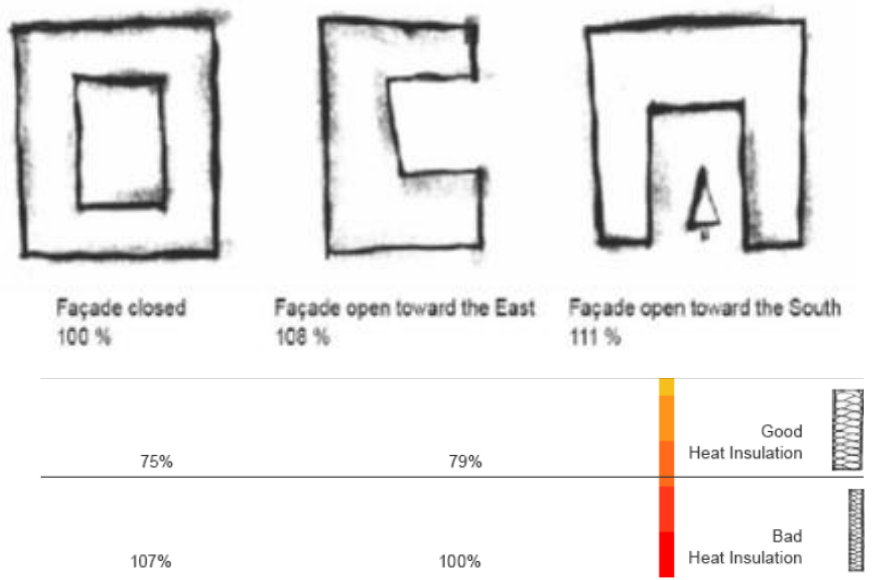

Figure (5) Influence of envelope area (A)/room volume (V) ratio on primary energy requirements

\subsubsection{Building Envelope}

(Alex Zimmerman, 2009)

The façade of a building constitutes the interface between outside and indoor climatic conditions. While indoor climate in rooms that are occupied year round tends to fluctuate only within a narrow corridor of 4 to $8 \mathrm{~K}$, outdoor climate can present temperature differences of up to $80 \mathrm{~K}$, depending on location.

Good heat insulation, however, not only makes sense for countries subjected to long lasting, cold outdoor climate. This becomes clear once we take a closer look. For countries with a hot outdoor climate of up to $50^{\circ} \mathrm{C}$, as are found in the Middle East, there is nearly the same temperature gradient (outdoor/ indoor climate, 25 to $30 \mathrm{~K}$ ) as in 
Germany, only in reverse. The building does not lose heat to the outside but, rather, gains it from there. In order to uphold thermal comfort levels, one does not need to heat but cool.there are climate zones that do not require high levels of heat insulation on account of their continental, even outdoor climate. In Central Africa, for instance, outdoor temperature presents evenly, day and night, winter and summer, somewhere between 10 and $30^{\circ} \mathrm{C}$. (fig 6)
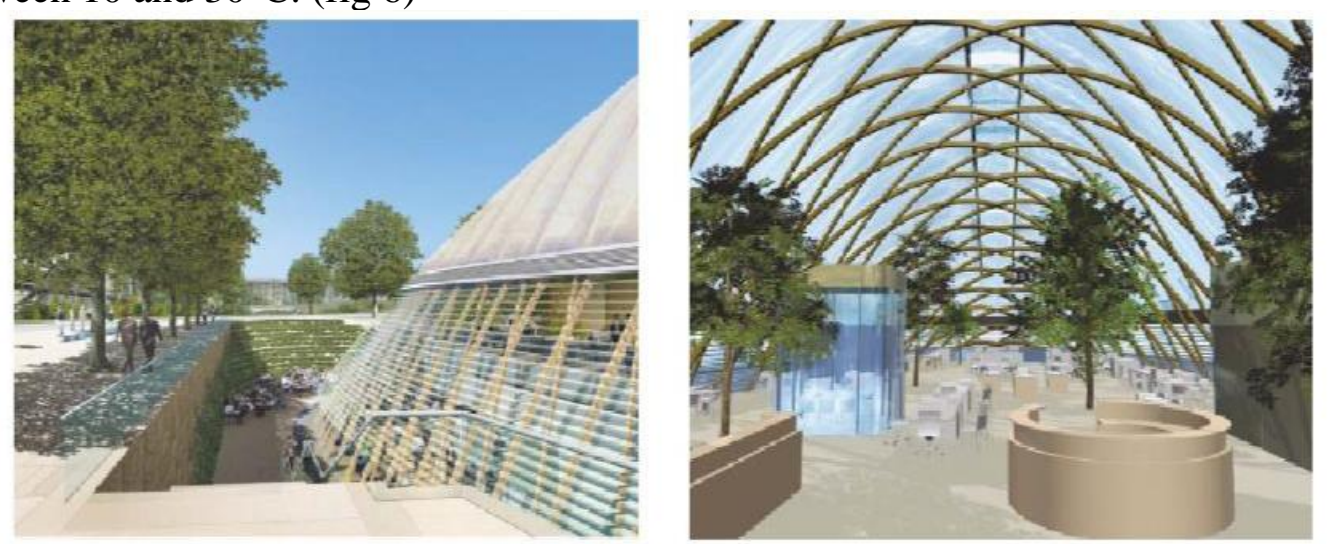

Fig 6 Outer and interior view, competition design for a customer center.Architects: Petzinka Pink Technologist Architecture ${ }^{\circ}$, Dusseldorf (Alex Zimmerman, 2009)

\subsection{Rating Systems for Sustainable Buildings}

\section{Structure of Rating Systems}

The different aspects are sorted in over all categories, like energy or quality groups, economy and social demands. For each aspect, one or more benchmarks exist, which need to be verified in order to meet requirements or obtain points.

Depending on the method used, individual points are either added up or initially weighted and then summed up to obtain the final result. The number of points is ranked in the rating scale, which is divided into different levels: The higher the number of points, the better the certification

Types of certifications :-

- LEED® - Leadership in Energy and Environmental Design

- BREEAM - BRE Environmental Assessment Method

- DGNB - German Sustainable Building Certificate (GeSBC)

- Energy Performance Directive

\subsection{Building Performance Analysis (BIM)}

Building Information Modeling (BIM) is an approach to design that uses intelligent 3D computer models to create, modify, share, and coordinate information throughout the design process. Many AEC firms are using BIM to drive a more efficient design process.

In addition to driving a more efficient overall design process, BIM is powerful for sustainable design because it can help you iteratively test, analyze, and improve your design. This is called Building Performance Analysis (BPA). When used well, using BIM for building performance analysis can help you design sustainably.

At the core of BIM is the information that's stored in the model. All of this data is stored and referenced in a back-end database that's an integral part of the model. (fig 7 ) 


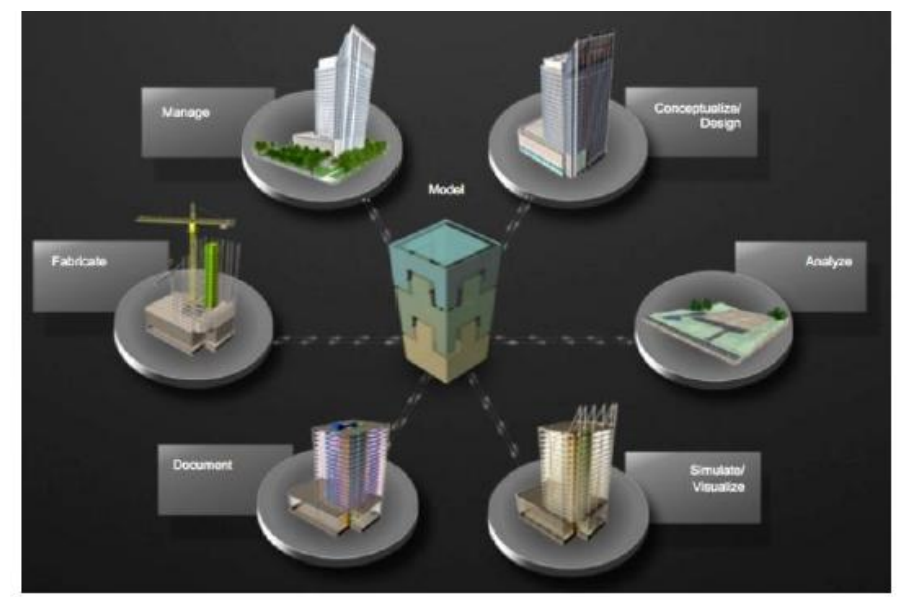

Fig 7 - BIM uses a central model that can be extended for multiple purposes, including performance analysis http://sustainabilityworkshop.autodesk.com/

Using this information, analysis engines can run simulations on things like HVAC sizing, energy use, water use, shading, and lighting levels. You can then make better design decisions by analyzing and documenting the expected performance of your design.

The infographic below explains how BIM and BPA are related, and what types of analyses can be considered building performance analysis. Whole Building Energy Analysis takes into account the interdependencies of the building as a whole system, so it is a particularly useful way to "keep score" as you work to reduce building energy use. Other performance studies like day lighting and solar radiation can help you improve aspects of the design. These studies are most effective when done in conjunction with energy analysis.

\subsection{Conclusion}

- There Are Two Important Details That Explain Confusion About The Fundamental Difference Between 'Green' And 'Sustainable. Significant Gains Can Be Made In Efforts To Combat Climate Change By Adopting Green Building Techniques.

- Between Building-Related Environmental Improvements And Increased Building Economics And Value, As Well As Increased Occupant Productivity

- Application Of Green Building Concepts Can Yield For Savings During The Construction Process. Measures That Are Relatively Easy To Implement Can Result In Savings To The Contractor. Besides Providing Significant Environ Mental And Occupant Benefits, Green Building Offers Several Business Advantages To Both Profit And Nonprofit Affordable Developers Who Include It As Part Of Their Business Practices.

- The orientation of a given building especially of its transparent surfaces influences its energy budget due to the different heights from which solar radiation hits. The façade of a building constitutes the interface between outside and indoor climatic conditions.

- Rating systems was developed to measure the sustainability level of Green Buildings and provide best practice experience in their highest certification level. The certification process means quality as successful assessments are convenience, usability and adequate effort during the different stages of the design process. surance for building owners and users. Important criteria for

- Green Buildings are buildings of any usage category that subscribe to the principle of a conscientious handling of natural resources. This means causing as little environmental interference as possible, the use of environmentally friendly

Recommendations materials that do not constitute 
- The Country Should Apply The Green Building Principles At All Its Establishment And To Reduce The Energy Consumption

- Architectural and scientific institutions are responsible for the transfer of green awareness architectural to the public

- Laws should be applied to reduce energy consumption to reduce the warming of thermal setting

- Construction Law must be developed to fit with the principles of green architecture

\section{REFERENCES}

1. (n.d.). Retrieved from http://www.architecture-student.com.

2. (n.d.). Retrieved from (Www.Renewableenergyaccess.Com).

3. (n.d.). Retrieved from See more at:

http://sustainabilityworkshop.autodesk.com/buildings/building-performance-

analysis-bpa\#sthash.qqnNx6EJ.dpuf.

4. (Www.Arctitecture2030.Org). . (n.d.).

5. Alex Zimmerman, A. (2009). Integrated Design Process Guide. Canada: Canada Mortgage and Housing Corporation.

6. baumert, K. a. (2005). Navigating the Numbers - Greenhouse Gas Data and International Climate . Hyacinth Billings: Library of Congress.

7. CJ, K. (2008). Sustainable Construction: Green Building Design and Delivery. In K. CJ, Sustainable Construction: Green Building Design and Delivery. Hoboken, NJ.: Wiley.

8. Craig Nielson, LEED AP;Connie Baker Wolfe. ( 2009 ). GREEN BUILDING GUIDE Design Techniques, Construction Practices \& Materials for Affordable Housing. 3120 Freeboard Drive, Suite 201, West Sacramento, California 9569: RCAC Corporate Office.

9. Douglas, B. C. (2009). Global Sea Rise: A Redetermination.

10. (2009). Greenhouse Gas Inventory Report. U.S.

11. Harris, K. (2016, 2 17). http://www.fosterandpartners.com. Retrieved from http://www.fosterandpartners.com/news/archive/2015/11/foster-partners-winsmaspero-triangle-district-masterplan-design-competition/:

http://www.fosterandpartners.com/news/archive/2015/11/foster-partners-winsmaspero-triangle-district-masterplan-design-competition/

12. Harris, K. (n.d.). http://www.fosterandpartners.com/news/archive/2015/11/fosterpartners-wins--maspero-triangle-district-masterplan-design-competition/. Retrieved from http://www.fosterandpartners.com/news/archive/2015/11/foster-partners-winsmaspero-triangle-district-masterplan-design-competition/:

http://www.fosterandpartners.com/news/archive/2015/11/foster-partners-winsmaspero-triangle-district-masterplan-design-competition/

13. http://egypt-gbc.org/history.html. (2016, 2 13). Retrieved from http://egyptgbc.org/history.html: http://egypt-gbc.org/history.html

14. http://egypt-gbc.org/purpose.html. (2016, 2 13). Retrieved from http://egyptgbc.org/purpose.html: http://egypt-gbc.org/purpose.html

15. http://egypt-gbc.org/ratings.html. (2016, 2 13). Retrieved from http://egyptgbc.org/ratings.html: http://egypt-gbc.org/ratings.html

16. Jaillon L, P. C. (2008). a Hong Kong case study. In P. C. Jaillon L, Sustainable construction aspects of using prefabrication in dense urban environmen (pp. 953966). 